\title{
(2) caras \\ () \\ OPEN ACCESS \\ Intra-articular horizontal dislocation of the patella: a rare injury and review of the literature
}

\author{
Vasileios Despotidis, ${ }^{1}$ Johannes Weihs, ${ }^{1}$ Zacharia Joseph, ${ }^{2}$ Lampros Gousopoulos ${ }^{3}$
}

Department of Orthopaedic Surgery and Traumatology, Inselspital University of Bern, Bern, Switzerland

${ }^{2}$ Department of Orthopaedic Surgery and Traumatology, Fiona Stanley Hospital, Murdoch, Perth, Western Australia, Australia

${ }^{3}$ Department of Orthopaedic Surgery and Traumatology, Hôpital du Valais, Martigny, Switzerland

\section{Correspondence to}

Dr Vasileios Despotidis; vasileios.despotidis@gmail. com and

Dr Lampros Gousopoulos; l.gousopoulos@gmail.com

VD and LG contributed equally.

VD and $L G$ are joint first authors.

Accepted 17 June 2020

Check for updates

(c) BMJ Publishing Group Limited 2020. Re-use permitted under CC BY-NC. No commercial re-use. See rights and permissions. Published by BMJ.

To cite: Despotidis V, Weihs J, Joseph Z, et al. BMJ Case Rep 2020;13:e232249. doi:10.1136/bcr-2019232249

\section{SUMMARY}

Acute traumatic intra-articular dislocation of the patella is not a common presentation in orthopaedic practice; less frequently observed than extra-articular dislocation of the patella. In some of these cases, closed reduction is not possible and an open reduction in the operating theatre must be performed. In this case report, we present an elderly patient with an intra-articular horizontal dislocation of the patella without any other bony or ligamentous lesions seen in a postreduction MRI. We conducted a literature review looking at intraarticular patella dislocations, identifying 64 published studies (articles, case reports and papers). The following sources of data were searched until December 2017: PubMed, OVID, Google Scholar, Scopus, using the search strategy of (intra-articular dislocation of patella, horizontal patellar dislocation) with no limitation on the year or language of publication. The patient presented in this case report was managed with a closed reduction under general anaesthesia, without the need of any surgical intervention. As proposed in the literature, the hypothesis of an intra-articular entrapment of the patella due to the trapped osteophytes of the superior pole of the patella into the intercondylar notch was thought to be the cause of intra-articular dislocation in this elderly patient.

\section{BACKGROUND}

This case report serves to highlight this infrequent trauma presentation in the elderly population as well and to remind medical practitioners that although rare, dislocation of the patella should be suspected in the case of locked knees, especially in patients with known osteoarthritic changes.

\section{CASE PRESENTATION}

A 92-year-old woman presented to the emergency department of Insel hospital in Bern, after a direct trauma to her right knee postmechanical fall. The patient presented with a locked knee in $100^{\circ}$ flexion and was unable to actively extend her knee. X-rays revealed an intra-articular dislocation of the patella with an entrapment of the upper pole in the intercondylar notch (figures 1 and 2). A fracture was not visible on the plain radiograph. The patient had a successful closed reduction of her intra-articular patella dislocation under a general anaesthetic. The closed reduction was straightforward, with direct pressure placed on the inferior pole of the patella and the knee put in flexion. The manipulation under anaesthesia was performed in the operating theatre as it was uncertain if a closed reduction would be possible. A cylindrical cast was applied for 3 days postprocedure, until the postreduction MRI was done to exclude any traumatic pathologies. The clinical examination after reduction revealed no haemarthrosis, no palpable dehiscence in the quadriceps tendon and an intact straight leg raise test.

\section{INVESTIGATIONS}

The postreduction X-rays (figure 3) showed adequate positioning of the patella in the trochlear groove. The patellar height was measured at 1.2 , using the Caton-Deschamps index. ${ }^{1}$ An MRI (figure 4) postreduction was performed and revealed no intra-articular pathology, with an intact quadriceps tendon and no intra-articular fragments. The MRI did however identify the presence of osteophytes at the superior pole of the patella and in the intercondylar notch, confirming the hypothesis of an intra-articular entrapment of the patella due to the trapped osteophytes of the superior pole of the patella into the intercondylar notch.

\section{DIFFERENTIAL DIAGNOSIS}

As the osteophytes appeared to be the reason for the dislocation, we considered an arthroscopic resection for further management of this patient, to help prevent further dislocations. The poor prognostic factors for further surgery were the patient's age and normal mobility status.

\section{TREATMENT}

Physical therapy was initiated on day 1 postprocedure, with weight bearing as tolerated in crutches and on the day of discharge, the patient was able to walk normally without the aid of crutches or need for a brace. After a 3-day admission, the patient was discharged from hospital.

\section{OUTCOME AND FOLLOW-UP}

In last outpatient follow-up, 1-year postinjury, she presented with full preinjury function of her knee, with no further recurrence of the dislocation and could return to her activities of daily living approximately after 6 weeks.

\section{DISCUSSION}

This rare condition was first described in the literature by Midelfart. ${ }^{2}$ Since 1887, 64 cases of an intra-articular patella dislocation have been reported in the world literature. ${ }^{3-60}$ Intra-articular dislocations of the patella are separated in two 


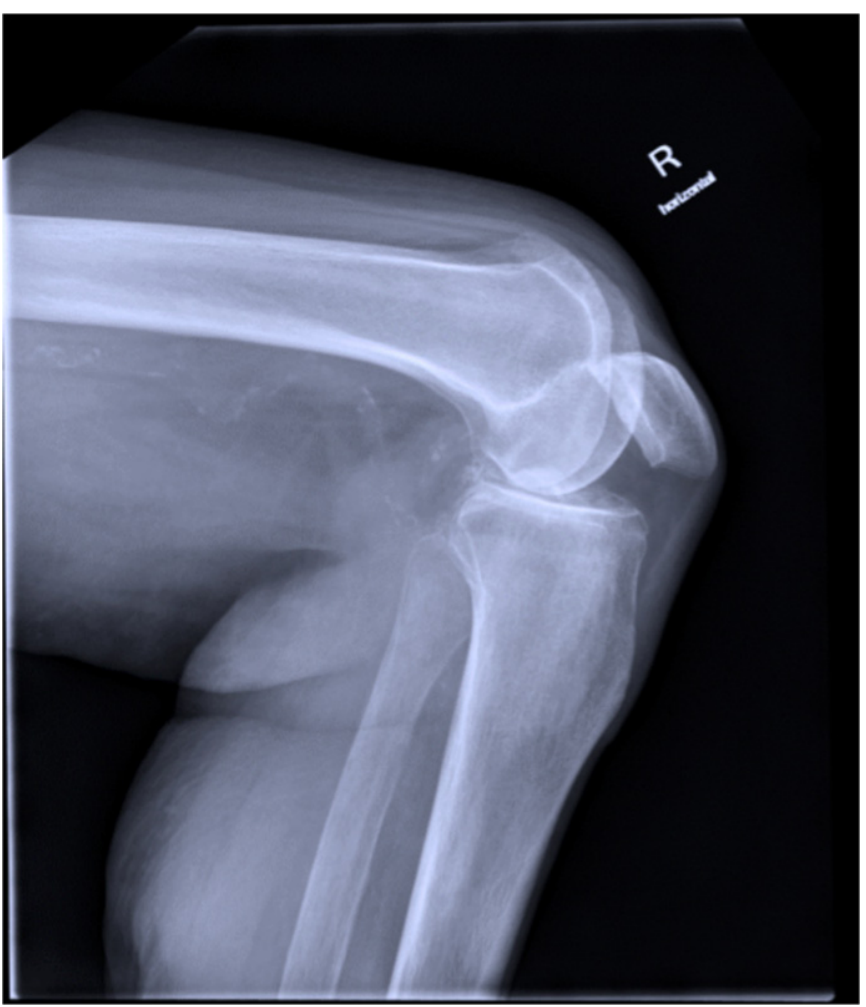

Figure 1 Lateral X-Ray of the affected knee.

groups: horizontal and vertical, according to the axis of rotation. The horizontal dislocation is more common and occurs after a direct trauma on a partially flexed knee, which leads to a rotation of the patella around its horizontal axis. When the knee joint is in flexion, the upper pole of the patella lies in front of the intercondylar groove, the initial traumatic blow, if exerted on the upper pole, pushes the patella posteriorly and it may lock in flexion.

Horizontal rotation can detach the quadriceps tendon from the upper patella pole, and the articular surface faces distally to the tibia plateau. Less frequently, the lower pole of the patella tears away from the patellar tendon and becomes locked within the joint, with its articular surface pointing

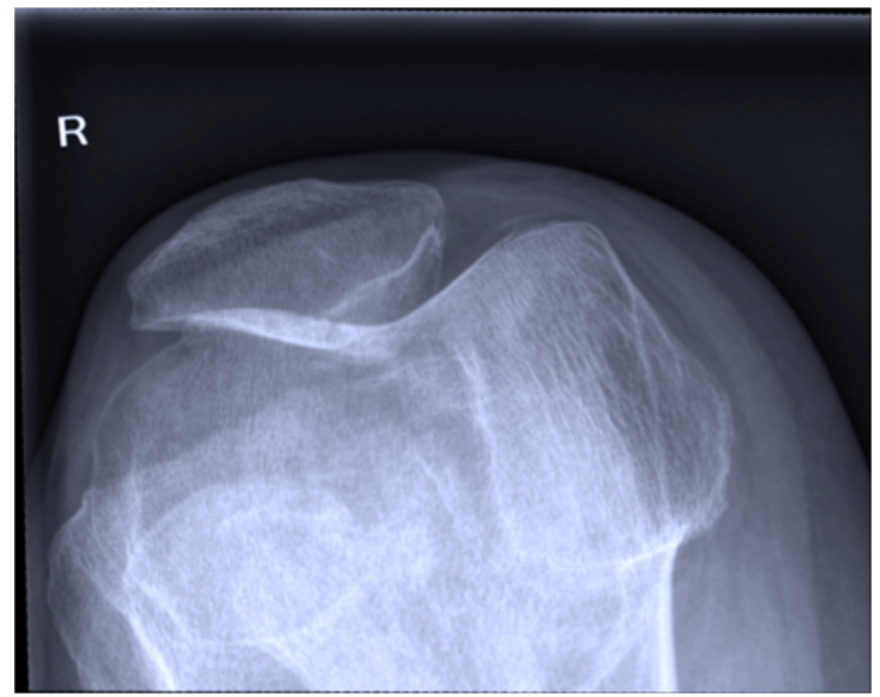

Figure 2 Sunrise X-Ray of the affected knee.

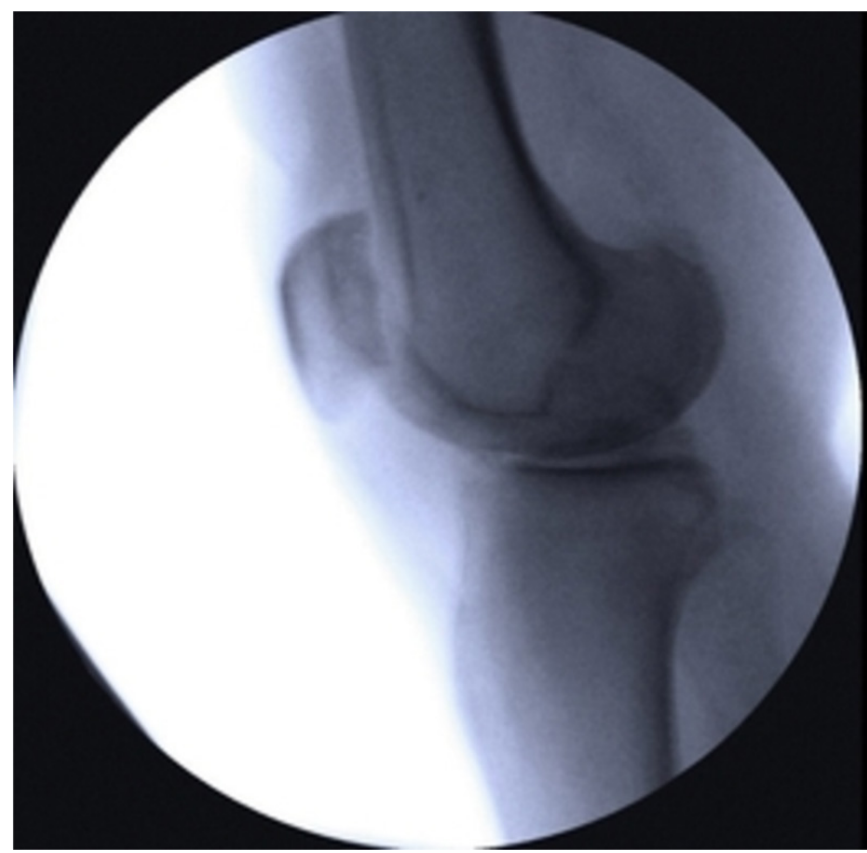

Figure 3 Post-reduction X-ray.

proximally. ${ }^{37385657}$ In the less common vertical type of dislocation, the patella rotates on its vertical axis, with the edge lying in the notch. The articular surface faces medially or laterally, and the patient presents with the knee in near full extension. ${ }^{6162}$

According to our bibliographical analyses, the majority of the dislocations $(58 \%, 37 / 64$ patients) underwent an open reduction, ${ }^{21-54}$ whereas only $31 \%$ (20/64 patients) could be reduced with a closed reduction..$^{3-11}$ 55-61 In the other $11 \%$ of cases, the reduction and anaesthesia methods were not clearly mentioned. Murakami ${ }^{35}$ has proposed that successful

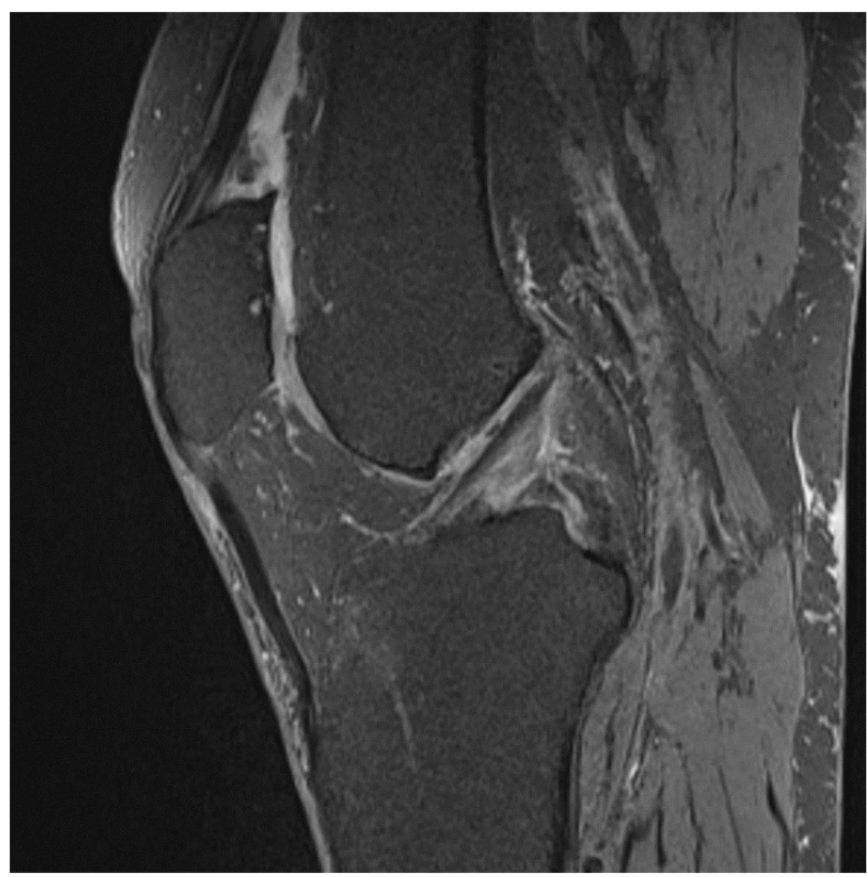

Figure $4 \mathrm{MRI}$ of the knee after reduction which shows an intact quadriceps tendon and the presence of the presence of osteophytes at the superior pole of the patella. 
manipulative reduction depends on the degree of locking of the patella within the joint. Although successful closed reductions have been reported under sedation with ethonox, ${ }^{4}$ chloroform ${ }^{36}$ and even with intra-articular anaesthetic solution, ${ }^{55}$ the importance of general anaesthesia with adequate muscle relaxation has been emphasised to prevent any further chondral damages. ${ }^{6}$

The mean age of the patients with this rare pathology was 31.9 years (range 9-93 years). The mean age of patients who underwent an open reduction was 22.4 years (range 9-88 years) and the mean age of patients with closed reduction was 45.3 years (range 10-93 years). It is becoming clear that a successful closed reduction under anaesthesia may be expected in the elderly group, in whom the dislocation is liable to occur owing to osteophyte locking rather that true impaction of the patella and the injury mechanism does not involve a high energy trauma.

An open reduction allows an inspection of the soft tissues and accurate repair if needed and should remain the preferred treatment for intercondylar patellar dislocation in young patients where the mechanism force is more important and an associated soft tissue injury more likely to happen due to lax patellar attachments. ${ }^{22}$

\section{Learning points}

- Our case demonstrated that the patella had dislocated horizontally, and the reason of the entrapment was considered to be the osteophytes of the superior pole of the patella in the intercondylar groove.

- This case report serves to highlight the existence of this rare condition in the elderly population as well and to remind medical practitioners that although rare, dislocation of the patella should be suspected in the case of locked knees, especially in patients with known osteoarthritic changes.

- An open reduction allows an inspection of the soft tissues and accurate repair if needed and should remain the treatment of choice be intercondylar patellar dislocation in young patients where the mechanism force is more important and an associated soft tissue injury is more likely to happen.

- Previous case reports confirm that the extensor mechanism usually remains intact as in our case but there can be varying degrees of quadriceps tendon avulsion. ${ }^{529} \mathrm{Six}$ (6/64) patients with intra-articular dislocation were found to have an associated avulsion of the distal quadriceps tendon, 82227294251 one of them had additionally a medial patellofemoral ligament tear, ${ }^{22}$ whereas one case had a coronal shear femoral Salter-Harris type III fracture in a 15 -year-old boy. ${ }^{59}$

Contributors LG and VD searched, analysed the literature and wrote the case report, have the full responsibility of the design and the acquisition of the data, VD also obtained the consent form, ZJ has revised the case report, JW has revised, verified the quality of the case report and finally approved the version published.

Funding The authors have not declared a specific grant for this research from any funding agency in the public, commercial or not-for-profit sectors.

Competing interests None declared.

Patient consent for publication Obtained.

Provenance and peer review Not commissioned; externally peer reviewed.

Open access This is an open access article distributed in accordance with the Creative Commons Attribution Non Commercial (CC BY-NC 4.0) license, which permits others to distribute, remix, adapt, build upon this work non-commercially, and license their derivative works on different terms, provided the original work is properly cited and the use is non-commercial. See: http://creativecommons.org/ licenses/by-nc/4.0/.

\section{REFERENCES}

1 Caton J, Deschamps C, Chambat P, et al. Les rotules basses a propos de 128 observations. Rev Chir Orthop 1982;68:317-25.

2 Midelfart V. En sjelden luxation of patella. Norsk Magazinfor Laegevidenskaben $1887 ; 588$

3 Frangakis EK. Intra-Articular dislocation of the patella. A case report. J Bone Joint Surg Am 1974;56:423-4.

4 Choudhary RK, Tice JWS. Intra-Articular dislocation of the patella with incomplete rotation-two case reports and a review of the literature knee 2004.

5 Feneley RCL. Intra-Articular dislocation of the patella. J Bone Joint Surg Br 1968;50:653-5.

6 van den Broek TA, Moll PJ. Horizontal rotation of the patella. A case report with review of the literature. Acta Orthop Scand 1985:56:436-8.

7 Aud G. Downward dislocation of the patella. J Am Med Assoc 1922;78:1457-8.

8 Deaderick C. Case of rupture of quadriceps femoris tendon with dislocation of patella beneath the intercondyloid groove of the femur. Ann Surg 1890;11:102-3.

9 Gore DR. Horizontal dislocation of the patella. JAMA 1970:214:1119.

10 Kager A. Bericht iiber einen seltenen fall von horizontaler Verrenkung Der Kniescheibe. Zentralb/ chir 1957:82:111-3.

11 Lamprecht W. Die Horizontalluxation Der patella. Chirurg 1948;19:378-9.

12 Jahangir N, Umar M. Spontaneous superior Patellar dislocation in young age: case report and reduction technique. J Surg Case Rep 2017;2017:rjx036.

13 Pagdal S, Lande 0, Jadhav U. Intra-articular dislocation of patella reduced by closed method - A rare case report. J Clin Orthop Trauma 2016:7:118-20.

14 Garner JP, Pike JM, George CD. Intra-Articular dislocation of the patella: two cases and literature review. J Trauma 1999:47:780.

15 Packer GJ, Owen RJ, Nsouli AZ. Intra-Articular dislocation of the patella. Arch Emerg Med 1992:9:244-5.

16 Chauhab A. Horizontal intraarticular dislocation of patella-A case report and review of literature injury extra 2014.

17 Nielsen CF, Fridén T, Ryd L. Inferior locking of the patella: a case report. J Trauma 1993:34:467-8.

18 Joshi R. Inferior dislocation of the patella injury. Case Report 1997;28:389-90.

19 McCarthy TA, Quinn B, Pegum JM. Inferior dislocation of the patella: an unusual cause of a locked knee. Ir J Med Sci 2001:170:209-10.

20 Bankes MJK, Eastwood DM. Inferior dislocation of the patella in the degenerate knee. Injury 2002;33:528-9.

21 McHugh G, Ryan E, Cleary M, et al. Intra-Articular dislocation of the patella. Case Rep Orthop 2013:2013:1-3.

22 Kramer DE, Simoni MK. Horizontal intra-articular Patellar dislocation resulting in quadriceps avulsion and medial patellofemoral ligament tear: a case report. J Pediatr Orthop B 2013:22:329-32.

23 Theodorides A, Guo S, Case R. Intra-Articular dislocation of the patella: a case report and review of the literature. Injury Extra 2010;41:103-5.

24 Dimentberg RA. Intra-Articular dislocation of the patella: case report and literature review. Clin J Sport Med 1997:7:126-8.

25 Sarkar SD. Central dislocations of the patella. J Trauma 1981;21:409-10.

26 Garrison RT, Mc Cabe JB. An unusual case of intraarticular dislocation of the patella. Ann Emerg Med 1984

27 Shaw D, Giannoudis P, Archer I. Intra-Articular dislocation of patella injury 1995;26:273-4.

28 Schulte KR, Tearse DS. Intra-Articular dislocation of the patella lowa. Orthop J 1993.

29 Brady TA, Russell D. Interarticular horizontal dislocation of the patella. A case report. $J$ Bone Joint Surg Am 1965;47:1393-6.

30 Brown KP. Interarticular dislocation of the patella. Edinburgh Med. J 1924:31:403-6.

31 Cheesman WS. Xi. dislocations of the patella, with rotation on its horizontal axis. Ann Surg 1905;41:107-14.

32 Donelson RG, Tomaiuoli M. Intra-Articular dislocation of the patella. A case report. J Bone Joint Surg Am 1979:61:615-6.

33 Henrichson A. Ein fall von Luxatio Patellar horizontalis inferior. Zentralb/ Chir 1923:30:62-7.

34 Penry Jones J, Jones JP. Interarticular dislocation of the patella. Br J Surg 1928;16:338-9.

35 Mowbray MAS, Allum R. Horizontalintra-articular dislocations of the patella. J Trauma 1980;20:99-100

36 Murakami Y. Intra-Articular dislocation of the patella. A case report. Clin Orthop Relat Res 1982;171:137-9.

37 Newman D, Rutherfurd $\mathrm{H}$. Two cases of dislocation of the patella, one upwards and one downwards. Lancet 2019:190-1.

38 Perkins JW. Hitherto undescribed dislocation of the patella endwise. J Am Med Assoc 1920;74:388.

39 Rochedieu. A propos d'un cas de luxation horizontale inférieure de la rotule. Zentralb/ Chir 1921:48:1701-2.

40 Rutherfurd H. Downward dislocation of the patella. Br J Surg 1920;8:524-6. 


\section{Unusual presentation of more common disease/injury}

41 Schmidt E. Ein fall von luxation Der patella MIT Abriss Der Quadricepssehne. Zentralbl. Chir 1900;27:1023.

42 Schiittemeier W. Die Horizontal- Oder Einklemmungsluxation Der patella. Chirurg 1947;18:364-5.

43 Scott CM. Two rare cases of dislocated patella. JAMA 1924;82:1198

44 Steinmann F. Horizontale Luxation der Patella. In: Lehrbuch Der Funktionellen Behandlungder Knochenbriiche und Gelenk verletzungen. Verlag von Ferd Enke, Stuttgart, 1919: 212-3.

45 Stover CN. Interarticular dislocation of the patella. JAMA 1967;200:996.

46 Szuman L. Ueber eine seltene form von Patellaluxation. Arch Klin Chir 1889;259:642-50.

47 Wildt A. Ein fall von Einklemmungsluxation Der patella. Munch Med Wochenschr II 1908:2705-6.

48 Wortmann V. Horizontale Patellaluxation. Monatsch. Unfallheilk 1959;62:196-8.

49 Farmer AW. A case of intra-articular dislocation of the patella. Can Med Assoc J $1931 ; 25: 706-7$

50 Hennings J. Die Avulsionsfraktur Der patella MIT intraartikulärer Dislokation Unfallchirurg 2012

51 Desai A, Allcock S, Hardy FSK. Horizontal intra-articular dislocation of the patella in an 88-year-old woman knee 1995:2:243-4.

52 Berenger $\mathrm{V}$, Pesenti $\mathrm{S}$, Ollivier $\mathrm{M}$, et al. Traumatic inter-condylar dislocation of the patella: report of two cases. Orthop Traumato/ Surg Res 2013;99:979-81.
53 Awan S, Parfitt A, Selvakumar P, et al. An unusual case of patella dislocation. J Accid Emerg Med 1999;16:301.

54 Nanda R, Yadav RS, Thakur M. Intra-Articular dislocation of the patella. J Trauma 2000;48:159-60.

55 Yoshino N, Takai S, Nakamura S, et al. Recurrent horizontal dislocation of the patella in the sagittal plane. A case report. J Bone Joint Surg Am 1996;78:278-80.

56 F J A. Intercondylar dislocation of the patella. S Afr Med J 1944;18:66

57 Gledhill R, Murray J. McIntyre Interarticular dislocation of the patella. Can J Surg 1968;11:57-9.

58 Potini VC, Gehrmann RM. Intra-Articular dislocation of the patella with associated Hoffa fracture in a skeletally immature patient. Am J Orthop 2015;44:E195-8.

59 Yoshioka S. Two cases of inferior dislocation of the patella with impaction into the femoral Trochlea of osteophytes on the superior pole of the patella case reports in Orthopedics 2013.

60 Colville J. An unusual case of intra-articular dislocation of the patella. Injury 1978:9:321-2.

61 Kaufman I, Habermann ET. Intercondylar vertical dislocation of the patella. A case report. Bull Hosp Joint Dis 1973;34:222.

62 Levin GD. Vertical axis rotational dislocation of the patella. Orthop. Rev 1978;7:83.

Copyright 2020 BMJ Publishing Group. All rights reserved. For permission to reuse any of this content visit https://www.bmj.com/company/products-services/rights-and-licensing/permissions/ BMJ Case Report Fellows may re-use this article for personal use and teaching without any further permission.

Become a Fellow of BMJ Case Reports today and you can:

- Submit as many cases as you like

- Enjoy fast sympathetic peer review and rapid publication of accepted articles

- Access all the published articles

Re-use any of the published material for personal use and teaching without further permission

Customer Service

If you have any further queries about your subscription, please contact our customer services team on +44 (0) 2071111105 or via email at support@bmj.com. Visit casereports.bmj.com for more articles like this and to become a Fellow 